\title{
Psycholinguistic Content of Complements in English and Ukrainian*
}

\section{Психолінгвістичний контент компліментарних висловлювань в англійській та українській мовах ${ }^{* *}$}

Ernest Ivashkevych ${ }^{1}$

Ph.D. in Psychology
Ернест Івашкевич ${ }^{1}$

кандидат психологічних наук

E-mail: erikguetta@mail.ru

https://orcid.org/0000-0001-7219-1086

ResearcherID: F-3865-2019

Iryna Perishko ${ }^{1}$

Ph.D. in Pedagogy,

Assistant Professor
Ірина Перішко ${ }^{1}$

кандидат педагогічних наук, доцент

E-mail: perishko irina@ukr.net

https://orcid.org/0000-0002-5232-5945

ResearcherID: AAN-3118-2020

Sabina Kotsur ${ }^{2}$

Master of Arts
Сабіна Коцур 2

магістр 3 лінгвістики

E-mail: sabina.kotsur@gmail.com

https://orcid.org/0000-0003-1112-2946

\section{Svitlana Chernyshova ${ }^{3}$}

Ph.D. in Philology,

Assistant Professor

\section{Світлана Чернишова ${ }^{3}$}

кандидат філологічних наук, доцент

E-mail: sveta.chernyshova@gmail.com

https://orcid.org/0000-0003-0284-2001

* This study is done within the framework of the Grant project (2020.01/0213).

** Дослідження виконане в рамках грантового проекту (2020.01/0213). 
Psycholinguistic Content of Complements in English and Ukrainian

${ }^{1}$ Rivne State University

of the Humanities

12, Stepan Bandera Str., Rivne, Ukraine, 33000

${ }^{2}$ Universität Salzburg

4/6, Kapitelgasse, 5020 Salzburg, Austria

${ }^{3}$ Taras Shevchenko National University of Kyiv

60, Volodymyrska Str., Kyiv, Ukraine, 01033
${ }^{1}$ Рівненський державний гуманітарний університет вул. Степана Бандери, 12, Рівне, Україна, 33000

${ }^{2} 3$ альибурзький Університет

Kapitelgasse, 4/6, 5020

Зальцбург, Австрія

${ }^{3}$ Київський національний університет ім. Тараса Шевченка $\triangle$ вул. Володимирська, 60, Київ, Україна, 01033

Original manuscript received September 27, 2019

Revised manuscript accepted August 21, 2020

\section{ABSTRACT}

The purpose of the article is: to show functions of compliments in the English and Ukrainian languages; to describe the differences between praise, flattery and compliments; to analyze a system of actual methods of modeling the associative content of the meanings of complementary expressions in the semantic field of the philological consciousness of the respondents of different ethnic groups (Englishmen and Ukrainians).

The methods of the research are: theoretical ones - categorical and structurallyfunctional analysis of the texts, the methods of systematization, modeling, generalization; empirical methods - the analysis of novels, a free associative experiment.

The results of the research. It was distinguished that among the respondents of the Ukrainian ethnic group we diagnosed the largest number of positive correlations between: the way of the explication of compliments in a form of a sentence and: syntactic constructions (phrases); semantically related compliments formed by the way of identity; creative compliments; semantically related compliments formed by the way of logical adjectivation and: semantically related compliments formed by the way of identity; semantically related compliments formed by the way of belonging, etc. The respondents of the English ethnic group had the highest number of positive correlations between: the way of the explication of compliments in a form of phrases and: semantically similar compliments; creative compliments; emotional and evaluative compliments and: semantically related compliments formed by the way of identity; semantically related compliments formed by the way of logical adjectivation, etc.

Conclusions. We'll formulate the psycholinguistic features of the explication of compliments in Ukrainian and English languages. Such features are: respondents of both Ukrainian and English ethnic groups are characterized by dominated subjective 
(ideosyncrasic) way of forming complementary expressions. English respondents are also dominated by emotional and evaluative way, while Ukrainians - by creative way in modeling the compliments. English people are more emotional in choosing phrases, word combinations and speech patterns that are complementary expressions, their speech is characterized by expressiveness and imagery. In turn, Ukrainians are more able to form creative expressions in their content, they form associative schemes, which, on the one hand, seem illogical, but, on the other hand, contain a creative context that enriches speech in a great degree, etc.

Key words: semantic field, psycholinguistic features of the explication of compliments, praise and flattery, creative compliments, logical adjectivation, emotional and evaluative compliments, semantically related compliments.

\section{Introduction}

Complements belong to the units of speech etiquette (Bates, Maechler, Bolker \& Walker, 2014; Goffman, 1981). Some scientists believe that compliments are characterized by the following qualities: a reaction, the expression of feelings, the attitudes (Aleksandrov, Memetova, Stankevich et. al., 2020). This class of language acts highlights the attitude of the speaker to the addressee and it is closely related to social etiquette (Cilibrasi, Stojanovik, Riddell \& Saddy, 2019; Schwartz \& Kroll, 2006).

Speaking about compliments, scientists single out a class of expressives, the purpose of which is to demonstrate the psychological state of the course of events, which in linguistics is expressed through a sentence (Batel, 2020; Valis, Slaninova, Prazak et. al., 2019). Researchers believe that a compliment is an illocutionary speech act, which belongs to a group of acts that reflects the attitude of a speaker to the person who listens to him/her (Lu, Wang, Guo, Zeng et. al. 2019; Pinker, 1991). In such a way K. de Bot carries a compliment to the class of acts of gratitude (Bot, 1992).

The units of the language which denote the etiquette some scientists refer to the statements that regulate interpersonal relationships with a partner and, as a result, convey the mental state of the speaker, his/her attitude to certain events (Blagovechtchenski, Gnedykh, Kurmakaeva et. al., 2019).

Illocutionary verbs to compliment, to approve, to praise, explaining the content of the emotional component of the utterance, are 
called a special kind of speech act, but they also are not performatives (Chen, 1993).

We agree with the point of view of researches, who think that verbal acts of praise, flattery and compliment are evaluative suggestions. They define them as specific emotional expressions that perform the function of evaluation in the process of communication (Dijkgraaf, Hartsuiker \& Duyck, 2017; Ferreira, Henderson, Anes, Weeks \& McFarlane, 1996).

When communicating directly to the addressee, the speaker is not limited by transferring of a certain information (the objective-modal task) or by the demonstration of his/her own attitude to the subject of speech (the subjective-modal task) (McClelland \& Elman, 1986). The speaker seeks to influence his/her partner in communication in order to obtain from him/her a certain reaction, to reach some condition or behavior which would meet the intentions and expectations of the addressee. In such a way, compliments are designed to affect the psyche and in a great degree regulate the behavior of the addressee. They, as a rule, do not add new logical content to a particular statement (Beauvillain, 1994; Mykhalchuk \& Bihunova, 2019; Ullman, 2001).

The main purpose of the compliment is the speaker's desire to please the addressee, emphasizing his/her external characteristics, mental abilities, skills, etc.; to highlight his/her unique qualities, to encourage, if it is necessary, to lift the addressee's spirit, to add some more confidence, that can largely change his/her emotional state in a positive direction.

Compliments are characterized by a great perlocutionary power, and are often accompanied not only by a change in the emotional state of the addressee, because of the connection of compliments with different kinds of the activities is one of the important features of some valuable complementary expressions (Alexandrov, Boricheva, Pulvermüller \& Shtyrov, 2011; Lagrou, Hartsuiker \& Duyck, 2013). Having heard the compliment, the addressee receives an incentive to act in some a way. The speaker expresses complements as means of persuasion, agreement, because the evaluation of the activity influences positively onto the persuasion of another person. Complementary speech act is used to change the behavior of the addressee (Caramazza, Laudanna \& Romani, 1988). Having been based on the effort to emphasize some particular opinion, the speaker appeals, as a rule, to the emotions, feelings of the 
object of the influence. Lack of basic knowledge is usually replaced by emotions, various means of emotional influences (Ware, Damnee, Djabelkhir et al., 2017).

But the problem of psycholinguistic content of complements in English and Ukrainian is not actually resolved in Psychology.

According to the actuality of our research the aim of the article is: to show functions of compliments in the English and Ukrainian languages; to describe the differences between praise, flattery and compliments; to analyze a system of actual methods of modeling the associative content of the meanings of complementary expressions in the semantic field of the philological consciousness of the respondents of different ethnic groups (Englishmen and Ukrainians).

A person who appeals to another person by the way of emotional influences that are not supported by semantic information, is a person who wants to persuade another one to perform a certain action. But it is impossible to make compliments, to convict another person only by the help of emotions (Green, 1998). With the help of emotions you can make a person believe, but in this way it is impossible to form beliefs (Levelt, 1983). As a rule, with a purpose to persuade another person people use certain arguments, based on some reasons, for example:

«Well, you told me to get a job».

"Not this kind of job. You have a good brain, you speak three languages and appear to be intelligent» (Pilcher, 1992: 361).

Another example is in the Ukrainian language from the poem of the contemporary poetess L. Tereshko «Sistine Madonna» (in Ukrainian: «Сікстинська мадонна»):

«Яка ж вона - небесна чи земна?

Така смиренна, гідна і невинна,

Ноша у неї зовсім не людська, Між іншими Вона благословенна» (Tereshko, 2019: 5).

As a lot of linguists point out, compliments are characterized by illocutionary versatility (Fodor, 1983; Herbert, 1989; Taft, 2013). Under certain circumstances, they are able to replace the verbal acts of greetings, thanks, apologies, congratulations, etc. (Booth, MacWhinney \& Harasaki, 2000). Moreover, compliments, performing some uncharacteristic for them functions, can be used independently or accompanied by appropriate speech acts. 
«Smiling, he strode towards her».

"God, you're more beautiful than ever».

"You're looking very handsome and distinguished», she said (Ellis, 1991: 173).

In this dialogic unity, compliments independently perform the function of greeting:

"I've never seen anything as precious and as lovely as the two of you lying together» (Andrews, 1990: 383).

In this example the compliment is used to express gratitude along with the language act «Thank you»:

«Thank you, Luke. You're very nice» (Andrews, 1990: 383).

Compliments are also used to soften criticism, with remarks having been made by the conjunctions «but» or «though»:

«Why, Andrew!» she gasped. "You look wonderful. Are you going anywhere?»

«Do you like it?»

«Yes», she said, not quickly enough to please him. "It's frightfully smart - but», she smiled, "somehow it doesn't quite seem you!» (Cronin, 1957: 271).

The interesting approach to the interpretation of the illocutionary power of the compliment is expressed by the heroine of the play by O. Wilde:

«But you are not very clever at paying compliments. I'm afraid Margaret doesn't encourage you in that excellent habit. It's a great mistake on her part. When men give up saying what is charming they give up thinking what is charming» - Mrs. Erlynne (Wilde, 1961: 56).

Thus, compliments are characterized by multifunctionality of the illocutionary function, but their main purpose is, nevertheless, to create and to maintain positive characteristics of the process of communication.

There is a lot of common between compliments, flattery and praise. That is quite natural, because they convey a positive assessment of the speaker. For example, researches understand the expressions of praise, flattery and compliments as some relations of the generic concept to the specific ones, because, according to the scientist, the concepts of «flattery» and «compliments» are forms of manifestation of the emotional concept of «praise» (Herbert, 1990). Some foreign linguists 
(Hatzidaki, Baus, \& Costa, 2015) do not focus on the differences between "praise: and «compliments». According to S. Brédart, the compliment is always addressed to its object. The statement, such as «this girl has beautiful hair», denotes praise (Brédart, 1991).

The expressions of the praise and the compliments, indeed, are thematically very similar and interchangeable, as it was shown by the fact that the verbs to compliment and to praise and the nouns related to them can describe the same situations. For example:

«It was difficult for him to pay a compliment. He despised people who were lavish with their praises» (Galsworthy, 1975: 111). «...He even went so far as to say I'd been innovative the other day. That's praise indeed from him. He's not given to paying me compliments» (Bradford, 1990: 52).

Here is the example of complementary statements, when the explication of praise and compliments is used in the Ukrainian language (the poem «Gratitude» (in Ukrainian: «Вдячність») by L. Tereshko):

«За всі дарунки дякую Тобі:

За сина і тепло красуні-хати, I за онуків милих, дорогих,

Не смію Долю більшого прохати...

Всміхаються нам зорі у журбі,

Твій сад, черешня біля хати...

Тебе ми любимо, вклонясмось Тобі

За все, що випало в житті пізнати!» (Tereshko, 2019: 13).

In our opinion, the difference between the praise and the compliment is that the main purpose of praise is to praise the addressee for his/her actions. But it should be noted that this feature is not a full characteristic of a compliment. Praise is expressed after the person has performed a certain act, the activity, and a compliment does not refer to the action as a whole, but to its individual characteristics, qualities (or properties) of the person or to the objects which belong to the person. The compliment is expressed in relations to facial features, a physique, manifestations of intellect and a character, manners, a voice, etc. Here is the example of such a compliment in the Ukrainian language (poem «I return to our November» (in Ukrainian; «Повертаюсь у наш листопад») by L. Tereshko):

«Промайнули роки, і лягли сінокосів покоси.

Небагато набігло в скарбниию - лише п'ятдесят! 
А я бачу донині весільні розплетені коси

I яскраве проміння, яким обіймав листопад» (Tereshko, 2019: 12).

Praise is due to a speech or non-speech behavior of a person. If we deal with such kind of the act, its result greatly affects the activities of the speaker, and if this activity is positive, then we can say with sufficient confidence that it is praise. In such a way we can conclude that the praise is more sincere, because the speaker himself/herself is interested in performing actions (Zuniga \& Simard, 2019). On the one hand, the author of the compliment can always be accused because of the insincerity, because the relationships between the addressee and the positive qualities of the speaker can not be seen. On the other hand, the speaker finds himself/herself in less advantageous position, not fully possessing the quality ascribed to the object of a compliment (Ellis, 1987). That's why often we have difficulties because of a clear differentiation between flattery and compliment. For example, from the novel «Fatherless sons» by Dyson Carter:

«No, no. I can't sleep. I ruined everything. I failed them. It was my fault. They were sure I could win and look how I failed them! I didn't get the Union vote and I didn't get the women!»

«Hush!» said Anna Nelson gruffly. «You got far more votes than any of us thought possible!» (Carter, 2015: 379).

A speech act of praise usually appears as a reactive replica, illocutionary one, while a compliment is an independent, free expression only if it is not the result of a request from the side of a speaker (Kormos, 1999).

On that fact that the suggestion is praise are shown by the verbs which are the part of the compliment: to handle, to manage, to do, to get, to laugh, as well as the use of perfect forms and the Past Tense:

«You certainly seem to have handled things brilliantly» (Shaffer, 1984: 148).

«He couldn't get his favorite argument started» (Carter, 2015: 271). "The bedroom was filled with sunny daylight that couldn't be shut out with the blinds or the curtains, and he laughed boyishly about that» (Carter, 2015: 224).

Thus, despite the thematic, structural and lexical proximity of compliments and praise, they have the following differences: 
(1) praise refers to the action, and the compliment - to a particular quality (property) of the person, to the objects which belong to the subject;

(2) praise is more sincere than a compliment;

(3) compliment is illocutionary independent statement, and praise is often a reactive replica;

(4) there are lexical and grammatical differences between a compliment and praise.

When a speaker tells a compliment, it implies that he/she has certain thoughts, feelings, intentions, and his/her speech act is directed on the facilitation of certain behavior of the person (Crookes, 1989). The latter is obliged to the reality, with the help of which the person can feel his/her thoughts, feelings, intentions. If the speaker expresses a compliment, but does not feel the appropriate feelings, then such expression of this compliment is perceived insincerely. In some cases, the speaker tries to hide the display of the expression of compliment (Arbuthnott \& Frank, 2000).

When a person intentionally tells a lie, thereby misleading the addressee pursuing his/her own selfish goals, we have a deal with flattery. Flattery, as a kind of lie, is a case when the meaning becomes very important: the hidden goal of a liar can be achieved only in this case if his/her words are understood in the meaning he adds to them. This question arises whether a certain meaning of statements can be asserted on the basis of non-linguistic intentions of the addressee, and whether this intention is linguistic itself, in such a way the intention to use different meanings of words is absent (Derwing, Munro, Thomson \& Rossiter, 2009). According to this P. Sgall (1986) wrote, if he uses the language to express opinions or to clarify them, or, for example, to deceive somebody, then it should be noticed that his words are very important, and it is quite probable that he wants to say exactly what he says, but even in such a way a comprehensive, full understanding of his intentions to convince or to motivate the listeners can be a rather unreliable indicator of his words.

Thus, any knowledge of the speaker's intentions leads to the disclosure of the meaning of his/her statement, and, conversely, a correct understanding of this meaning by the addressee does not help a person to determine real intentions of the speaker. In such a way we can talk about the impossibility of expressing extralinguistic intentions by 
linguistic means. Therefore, distinguishing of flattery from a compliment is based on linguistic material, and it is almost impossible. In these cases, we have to rely solely on the content of a particular statement and on the broad non-verbal context of compliments.

Truth and falsehood are understood by us as moral categories. The requirement to tell only the truth is not always observed in the process of social communication. Moreover, etiquette presupposes several forms of moral hypocrisy: false modesty, «holy lies», traditional politeness. Such statements include some compliments. For example, some scientists (O’Donnell, MacGregor, Dabrowski, Oestreicher \& Romero, 1994) classify a compliment as flattery. Other researches (O'Brien, Segalowitz, Freed \& Collentine, 2007) have slightly different point of view. The scientists note that the compliment and flattery are only partially coincide. They conclude that the compliment should not be taken seriously as the absolute truth.

Flattery is as the «illegal member of social communication». This term is used by the speaker when he/she wants to gain trust and to persuade the addressee, to glorify him/her in his/her own eyes and in the eyes of the audience. Flattery usually plays the role of falsified information, which the addressee says in order to persuade the partner of communication and to get selfish benefits (Gilabert, 2007). We think that the functional purpose of flattery is not so unambiguous. By performing a verbal act with the use of flattery the speaker can encourage the addressee to make the contradictory relationships between the partner of communications, and they will show admiration, envy, dislike and even anger. The speaker who wants to lie always tries to hide his/her selfish goals and mislead the addressee. He/she will try to bring the flattery as close as it is possible to say a sincere compliment. Formally, flattery doesn't differ from a compliment. For example, in the following example from the context we see that the heroine dislikes Frank, but she flatters him, wants to get married with him because of money. It is impossible to recognize flattery based only on language factors, because flattery becomes quite clear only from the context:

«You are so smart, Frank» (Mitchel, 1973: 587).

"If I may ask, Dave...what's her reason? Love? In her situation, she wouldn't want to marry without love, she's a proud girl» (Carter, 2015: 205). 
However, in some cases, statements which denote flattering have their own characteristics. These characteristics can be compared with a compliment. Compliment, as a rule, is realized as a part of a simple sentence, flattery - as a part of simple and complex sentences. Flattery differs from a compliment by inflated emotionality, expressiveness, verbosity, the addressee receives the maximum assessment of his/her qualities:

«Handsomer boys than yours, Mr. Brodrick», she said, «it has seldom fallen to my lot to see. They are like the blessed angels in heaven». "Here he was being flattered and patted on the back by the very people who had poisoned his dogs» (Maurier, 1978: 130).

"Anna laughed heartily. "Pat a bit on tour face, Bessie, tour color's a trifle high today» (Carter, 2015: 266).

Flattery can also be a part of a phrase: «Master John, if I may say so», he said,

"you are looking better than I have ever seen you in my life, and that's the solemn truth. And what a great piece of sport you are making with these gray hounds of yours» (Maurier, 1978: 53).

At the same time, it is not always possible to persuade the addressee to hide the speaker's selfish goal. In this case the addressee may misinterpret the rules of the language etiquette, then we deal with the situation described by I. Kotlyarevskyi in «The Aeneid»:

«П'ять казанів стояло юшки,

А в чотирьох були галушки,

Боршу трохи було не з шість;

Баранів тьма було варених,

Курей, гусей, качок печених,

Досита, щоб було всім їсть.

Цебри сидушки там стояли

I браги повнії діжки;

Всю страву в вагани вливали

I роздавали всім ложки» (Kotlyarevskyi, 1982: 54-55).

To express any opinion, the speaker always tries to choose from a wide variety of linguistic means those that, in his/her opinion, in the best way meet the speaker's goals. A global problem of the use of a language is based on the fact that the same point of view can be expressed by different speech units. In certain situations may 
be synonymous expressions, different by their structure and lexical content. However, despite all varieties of linguistic means which help the person to express the idea, no one doubts that some patterns denote the standardity of the language. The use of statements always inevitably leads to more frequent statements, which become more acceptable, and thus move to units which are used with more greater frequency and are characterized by common use.

The diversity of the potential behavior of the speaker is characterized by limited number of regularly recurring situations and by stereotypical design of their content. After all, it is potentially possible that in fact we move in a very narrow space of a real people's behavior. Studying the peculiarities of spoken language, researchers note that the intentions of the speaker are usually not clear, they are not separated from each other. These intentions are also intertwined, mixed, bizarrely interacting with each other, syncretic and so on. Moreover, the speaker often does not know what exactly he/she wants to achieve by expressing a certain opinion, and successful communication is possible only due to the automatic skills of speech and thinking, with the help of which the person tells compliments.

J. Kormos (1999) also emphasizes the differences between the function of the language and the use of it. The scientist believes that there is the indefinite number of language uses that can not be systematized in any linguistic theory. The fact is in that opinion that the language can serve a variety of purposes, due to the fact that a language system consists of a small set of functional components of high generalization. These components are also compliments.

\section{Research methods and techniques}

The results of theoretical analysis of the explication of complementary expressions in English and Ukrainian allow us to state that information about the world as a whole is systematized by the consciousness of the person in a form of semantic (associative-verbal) field (by frames, scripts, semantic grid), the production and modeling of which is one of the means of representing the speech competence of the person. In this paradigm, we organized and conducted the empirical research of the features of explication of psycholinguistic content 
of complementary statements by the British and the Ukrainians by measuring the logical and semantic organization of thought and speech activity using the diagnostic potential of free associative experiment.

We'll substantiate our scientific position of the choice of this psychodiagnostic research methods. Free associative experiment is one of the most expedient for revealing objectively existing in the psyche of a native speaker semantic connections between words, as well as the definitions of linguistic and cultural specifics of speech behavior of the person. Using the method of free associations in order to evaluate complementary statements, we share the position of connectionism, the initial thesis of which is the principle of parallel information processing (Parallel Distributed Processing), which provides the possibility of using this method not only to establish links between two specific words determining the appropriate one to a particular word sample (pattern) activation of a particular segment of the semantic field of the philological consciousness of the subject.

The choice of free associative experiment as a method of carrying out this empirical research in the context of our article is due to its compliance with the objectives of the research program, active mode of functioning of the semantic field of philological consciousness of two ethnic groups (the Ukrainians and the English people). The choice of a free associative experiment was also largely due to the fact that it reduced the likelihood of interpreting the associative concept through a prism of the researcher's personal experience, providing material from native speakers with different subjective experiences and levels of culture.

\section{Participants}

The selection of the empirical research consisted of 4525 respondents in age from 20 to 60 tears old. From them 2348 belonged to the Ukrainian ethnic group (among them - 1150 women and 1198 men) and 2177 people belonged to the British respondents (of them there are 1052 women and 1125 men). In Ukraine the study research was organized in Rivne, in the UK - in London. The research continued during 2019, July-August, when the authors of the article were participated in the research internship in the UK. According to the 
method of selection of respondents, the sample should be considered a random one, which eliminates intentional distortion of the characteristics of a general data set.

The subject of the research was a system of actual methods of modeling the associative content of the meanings of complementary expressions in the semantic field of the philological consciousness of the respondents of different ethnic groups.

The hypothesis of the empirical research marked the assumptions about the significance of differences by the explication of complements in the process of deploying schemes for organizing associative-semantic content of compliments between respondents of different ethnic groups.

The procedure of the research involved the empirical study of the system of associative-semantic relations in the paradigm of logical-semantic organization of complementary statements by respondents of different ethnic groups. Respondents were asked to respond to the researcher's statement with some association (and / or associative series), which firstly appears in the respondents' philological consciousness and can be displayed as a psycholinguistic formula of a compliment. Reproduction of the associative complementary concept (as a specific case of the development of speech event), focused on the reflection of nuclear semantics of words by logogen and synthesis of adequate semantic complementary construct, required respondents to update the universal dynamic code of verbal cognitive system. We mean semantic connections between the elements of the semantic construct «a compliment», a selection of the most correct form of making meaning according to complementary statements and constructive development of a symbolic image in the paradigm of acquired personally significant experience. This analysis included the representation of associativesemantic content of the corresponding semantic series (a denotative representation of semantic units of one associative-semantic construct), repeatability of speech patterns having been included into the structure of complementary utterances, a frequency of typical verbal reactions among respondents (the absolute frequency of methods of the formation of meaning was calculated). All these allowed us to reconstruct the semantic field of formatting of complementary statements of respondents by the way of formation the compliments.

The initial data processing was carried out by the method of content analysis with the subsequent calculation of the average values 
of the obtained material. The computer statistical program IBM SPSS Statistics 19 («Statistical Package for the Social Science») was used to summarize and to analyze the results of the empirical research.

\section{The results of the research and their discussion}

It seems to us expedient and perspective to analyze a compliment from a concrete communicative category of linguistic means to providing analyses to the means of expression. We mean the amplification of compliments and their structural components, the amplification of some lexical units. The syntactic system of the language also has considerable opportunities for the expression of complementary expressions. However, in a real life, the diversity of linguistic means for language implementation can be reduced to a very limited range of specific models of speech patterns. The models which are typical, repetitive, regular, etc. appear for the researcher as a semantic form, starting from which we can move to the infinite variety of semantic elements, just as many linguistic realizations are reduced to limited ones by different types of structural schemes of word combinations and sentences.

The same denotative situation can be represented by different statements based on several models. For example:

1.11 like you in this dress.

1.2 I like your dress.

2.1 № 1. You are nice in this dress.

2.2 № 2. Your dress is nice.

2.3 You are a nice girl in this dress.

2.4 № 1 . You have a nice dress.

2.5 № 2. You are wearing a nice dress.

Despite the synonymy of these structures or statements, they can be divided into two groups: $1.1 ; 2.1$ (№ 1); 2.2 and 1.2; 2.1 (№ 2); 2.3 (№ 1, № 2). In the first group the emphasis is on the person himself/ herself, because the positive sign is expressed by a pronoun. In the second group the positive quality is reflected in the details of cloth, in its appearance. In terms of speech etiquette the first group is more desirable for the addressee. At the same time, it is possible to imagine a situation where a woman wants to hear a compliment about her new dress, wants this very important detail to be noted for her every time, 
and she does not hear a general description: "You are nice», which she has already heard for many times. If the compliment is spoken by a person who is stingy for praise, then the advantage of one or another option is insignificant, and the fact of saying a compliment will be important itself.

To build a statement of compliment it is necessary to distinguish, first of all, those compliments in which the speaker expresses his/her attitude to the object of this compliment, and those ones which are descriptive. It is also very important for us is the difference between these situations: I admire you. You are beautiful. The first type of compliment is represented by the following two models: Model 1.1. $\operatorname{Pr} 1+V+\operatorname{Pr} 2$. In a place of $\operatorname{Pr}$, as a rule, there is a pronoun $I$, seldom - We; in a place of $\operatorname{Pr} 2$ - the pronoun you, in a place of $V$ there are verbs which express a positive attitude: to like, to admire, to love, to enjoy, to be attracted, to be proud, to appreciate, to value, to adore and others.

Model 1.2. $\mathrm{Pr}+V+N / S C$. In this model nouns or lexical constructions which express additional meaning play a function of the appendix: "I like your dress». "I do like the way you meet things».

The second type of compliments is represented by the proposition «S $=X »$, where $X$ is a qualifying predicate that attributes some positive features to the subject. The predication of these features to the subject of the expression can be done by various linguistic means, but, first of all, by evaluative adjectives.

The core of complementary expressions (excluding modified nouns, such as beauty, brilliance and others) are adjectives which perform the functions of a predicate or the attribute. Adjectives due to their semantics, to a greater extent than other parts of speech are characterized by the presence of an evaluative semas in the semantic structure of a lexical model. Researchers drew her attention to the weakening of their actual significance and their actualization of signs of qualifying character, which leads to the induction of emotionalevaluative semas (Herbert, 1989). Other researchers (Sgall, 1986) also believe that assessment as the expression of the subject's attitude to the object finds the most adequate expression in the field of functioning the adjectives. There is no doubt that adjectives as a part of speech are characterized by their ability to express evaluation. 
As one of the main features of the meaning and use of adjectives R. Herbert (1989) calls the combination of semantic and pragmatic aspects of the language. Compliments use qualitative adjectives that denote features which have a quantitative characteristic, may be more or less pronounced. Qualitative adjectives belong to the monofunctional type of verbal signs, which perform only a predicative semiological function. This function is realized in two main semantic and grammatical functions of the language - an attributive one and a predicative function. Predicative statements are able to perform complementary functions, and without them the compliment is unthinkable. Attributive adjectives, performing a qualitative function in the sentence, do not directly perform the propositional function and can be omitted without violating the integrity of the sentence.

Analyzing attributive groups which are not isolated, because they are in the text, we can admit, that in many cases the adjective becomes a mandatory element of a complementary statement. As for the adjectives that function in the structure of compliments, the adjectives are the center of the expression in spite of their main function. If a compliment without the attributive adjective remains correct in its grammatical structure, it loses all its meaning in terms of the author's intention. For comparison, we'll propose the sentences: You are a nice girl \& You are a girl. Nouns girl (woman, boy, man, etc.) are predicative ones, they are insignificant and can be omitted without any loss of their semantics in the structure of the whole statement.

Similar lexical units can be explosive in terms of the syntactical organization of the sentence. Such situation arises due to the fact that, being a part of the rhyme, the subject indicates some its subjective features, and they attract considerable communicative interest, which helps the lexical unit to take a place of semantic and then syntactic key expression.

Compliments use generally evaluative and in their structure there are partially evaluative adjectives which characterize the features of the person's appearance, details of cloth, the person's mental, physical, moral qualities according to the following parameters:

(1) aesthetic characteristics (beautiful, wonderful, lovely, pretty, nice, charming, handsome, marvelous, attractive, gorgeous, splendid, good-looking, etc.);

(2) mental abilities (clever, smart, bright, wise, educated, witty, etc.); 
(3) moral qualities (brave, honest, generous, understanding, decent, loyal, romantic, courageous, etc.);

(4) skills and efficiency (efficient, diligent, hardworking, talented, etc.);

(5) physical qualities (strong, slim, slender, broad, etc.).

Praise can convey a positive assessment, while the word itself can have a negative meaning. The definition plays a dominant role in the statement which denotes a compliment and turns it from offensive one to a quite positive suggestion, which is quite acceptable: "You are beautiful little moron» (Salinger, 1982: 219). Thus, adjectives containing seven positive evaluations are a central part of compliments. In a case of eliminating the adjective, the statement becomes uninformative. In Table 1 there are the most frequently used adjectives in the structure of compliments in the English language.

Table 1. The most frequently used adjectives the structure of compliments in the English language

\begin{tabular}{|c|c|c|c|c|c|}
\hline No & $\begin{array}{l}\text { The adjective which has } \\
\text { a function of a compliment }\end{array}$ & $\%$ & No & $\begin{array}{l}\text { The adjective which has } \\
\text { a function of a compliment }\end{array}$ & $\%$ \\
\hline 1. & Beautiful & 16.1 & 17. & Attractive & 1.60 \\
\hline 2. & Good & 11.8 & 18. & Well & 1.59 \\
\hline 3. & Wonderful & 8.25 & 19. & Wise & 1.42 \\
\hline 4. & Lovely & 6.84 & 20. & Splendid & 1.38 \\
\hline 5. & Nice & 6.63 & 21. & Gorgeous & 1.32 \\
\hline 6. & Pretty & 6.62 & 22. & Perfect & 1.22 \\
\hline 7. & Young & 3.25 & 23. & Special & 1.21 \\
\hline 8. & Clever & 3.16 & 24. & Little & 1.19 \\
\hline 9. & Sweet & 3.08 & 25. & Kind & 1.02 \\
\hline 10. & Charming & 3.04 & 26. & Intelligent & 0.96 \\
\hline 11. & Smart & 2.88 & 27. & Brilliant & 0.91 \\
\hline 12. & Brave & 2.67 & 28. & Good-looking & 0.89 \\
\hline 13. & Fine & 2.65 & 29. & Blooming & 0.82 \\
\hline 14. & Marvellous & 2.25 & 30. & Interesting & 0.66 \\
\hline 15. & Handsome & 2.15 & 31. & Remarkable & 0.51 \\
\hline 16 & Great & 1.93 & & & \\
\hline
\end{tabular}

For comparison, we present the most frequently used adjectives in the structure of compliments in the Ukrainian language (see Table 2). In Table 3 there are results of the frequency of use of methods of explication of compliments by representatives of Ukrainian and English ethnic groups. It should be noted at once that there no differences of 
respondents neither in their age nor in gender, and the results were differed only by the characteristic of ethnic groups of respondents.

Table 2. The most frequently used adjectives the structure of compliments in the Ukrainian language

\begin{tabular}{|c|c|c|c|c|c|}
\hline No & $\begin{array}{l}\text { The adjective which has a } \\
\text { function of a compliment }\end{array}$ & $\%$ & No & $\begin{array}{l}\text { The adjective which has a } \\
\text { function of a compliment }\end{array}$ & $\%$ \\
\hline 1. & Гарна & 0.96 & 49. & Бажана & 0.74 \\
\hline 2. & Розумна & 0.45 & 50. & Непередбачена & 1.13 \\
\hline 3. & Турботлива & 0.93 & 51. & Загадкова & 1.26 \\
\hline 4. & Приваблива & 1.07 & 52. & Інтригуюча & 0.23 \\
\hline 5. & Сексуальна & 4.93 & 53. & Бездоганна & 0.63 \\
\hline 6. & Добра & 4.25 & 54. & Гармонійна & 0.84 \\
\hline 7. & Ніжна & 4.36 & 55. & Чуйна & 0.73 \\
\hline 8. & Мила & 2.73 & 56. & Зроблена & 0.09 \\
\hline 9. & Чарівна & 5.08 & 57. & Краща & 0.90 \\
\hline 10. & Чаруюча & 4.56 & 58. & Скромна & 0.63 \\
\hline 11. & Неповторна & 1.34 & 59. & Вишукана & 0.74 \\
\hline 12. & Щиросердечна & 0.41 & 60. & Ангельськи прекрасна & 0.61 \\
\hline 13. & Незабутня & 0.93 & 61. & Природна & 0.34 \\
\hline 14. & Непереборна & 0.36 & 62. & Щира & 0.41 \\
\hline 15. & Шикарна & 2.64 & 63. & Дружелюбна & 0.25 \\
\hline 16. & Сліпуча & 0.21 & 64. & Розуміюча & 0.27 \\
\hline 17. & Жагуча & 0.12 & 65. & Таємнича & 0.40 \\
\hline 18. & Фантастична & 2.97 & 66. & Мрійлива & 0.57 \\
\hline 19. & Божественна & 0.43 & 67. & Приваблива & 0.63 \\
\hline 20. & Заворожлива & 0.14 & 68. & Іскрометна & 0.47 \\
\hline 21. & Ангельська & 0.17 & 69. & Хвилююча & 0.38 \\
\hline 22. & Промениста & 0.23 & 70. & Ваблива & 1.72 \\
\hline 23. & Пекельно божественна & 0.27 & 71. & Незрівнянна & 1.28 \\
\hline 24. & Яскрава & 0.31 & 72. & Безкорислива & 0.71 \\
\hline 25. & Чуйна & 0.97 & 73. & Безпосередня & 0.83 \\
\hline 26. & Прегарна & 0.12 & 74. & Звабна & 0.21 \\
\hline 27. & Карколомна & 0.07 & 75. & Одурманююча & 0.17 \\
\hline 28. & Струнка & 0.13 & 76. & Життєрадісна & 0.27 \\
\hline 29. & Зваблива & 0.34 & 77. & Усмішлива & 0.16 \\
\hline 30. & Кокетлива & 0.56 & 78. & Соромлива & 0.47 \\
\hline 31. & Витончена & 0.97 & 79. & Запальна & 0.34 \\
\hline 32. & Граціозна & 0.83 & 80. & Чесна & 0.58 \\
\hline 33. & Весела & 4.37 & 81. & Збудлива & 2.78 \\
\hline 34. & Енергійна & 0.74 & 82. & Щиросердна & 0.97 \\
\hline 35. & Креативна & 0.15 & 83. & Грайлива & 0.83 \\
\hline 36. & Стильна & 0.93 & 84. & Феєрична & 2.38 \\
\hline 37. & Комунікабельна & 0.44 & 85. & Цілеспрямована & 0.11 \\
\hline
\end{tabular}


Psycholinguistic Content of Complements in English and Ukrainian

\begin{tabular}{ll:lll}
\hline 38. Тактовна & 0.33 & 86. & Чудова & 3.71 \\
39. Чудесна & 4.36 & 87. Жіночна & 0.13 \\
40. Романтична & 0.25 & 88. Блаженна & 0.07 \\
41. Різнобічна & 0.10 & 89. Незрівнянна & 0.27 \\
42. Казкова & 4.26 & 90. Промениста & 0.14 \\
43. Симпатична & 0.43 & 91. Ненаглядна & 0.18 \\
44. Неуявна & 0.56 & 92. & Необхідна & 0.03 \\
45. Сдина & 0.12 & 93. & Дивна & 0.07 \\
46. Ласкава & 0.74 & 94. Зворушлива & 0.27 \\
47. Солоденька & 1.97 & 95. Мініатюрна & 0.18 \\
48. Запаморочлива & 0.38 & 96. Сама-сама & 4.92 \\
\hline
\end{tabular}

Further ranking of the frequency of use of associative schemes for the explication of complements allowed us to state that the most represented for respondents of both Ukrainian and English ethnic groups is a subjective (ideosyncrasic) way of forming complementary statements, while the English respondents predominantly use emotionally evaluative compliments, while Ukrainians prefer to use creative ones. For example, the emotional and evaluative associative schemes of Englishmen include: marvelous; gorgeous; perfect; remarkable; brave - gorgeous; great intelligent; great - attractive; great - brilliant. Creative associative schemes are presented by such example, as: pretty - young. The following examples we received in the group of Ukrainians. Emotionally evaluative compliments are: неповторна - вишукана; незабутня непереборна; сліпуча - промениста; карколомна - одурманююча; казкова - ангельськи прекрасна; грайлива - феєрична; необхідна приваблива; єдина - ненаглядна; феєрична - прегарна. There are such creative associative schemes, which are used by Ukrainian respondents: непередбачена - карколомна; приваблива - сексуальна; чаруюча - неповторна; иикарна - жагуча; промениста - пекельно божественна; яскрава - незрівнянна; яскрава - чуйна; сексуальна карколомна; зваблива - кокетлива; гармонійна - незабутня; чуйна краща; скромна - вишукана; ангельськи прекрасна - запаморочлива; ваблива - незрівнянна; звабна - одурманююча; таємнича соромлива; збудлива - життєрадісна; щиросердна - вишукана; креативна - феєрична; стильна - казкова; комунікабельна цілеспрямована; романтична - грайлива; різнобічна - незрівнянна; неуявна - краща; єдина - ласкава; солоденька - романтична; запаморочлива - шикарна; жіноча - стильна; незрівнянна промениста; ненаглядна - зворушлива; стильна - феєрична;

(C) Ivashkevych E., Perishko I., Kotsur S. \& Chernyshova S. 
романтична - чуйна; блаженна - одурманююча. The difference in the results according to emotionally evaluative way of formation of complementary statements between English and Ukrainians is significant at the level of significance of differences in results $0,01 \quad(\mathrm{r}=3.318$, $\rho<0.01$ ), which indicates that English people are more emotional in the choice of phrases, word combinations, speech patterns, which belong to complementary expressions, their speech is characterized by expressiveness and imagery. In turn, Ukrainians are more able to form creative expressions in their content, they modelate associative schemes, which, on the one hand, seem as illogical ones, but, on the other hand, contain a creative context that enriches their speech in general $(r=3.458, \rho<0.01)$.

The other largest group according to the criteria of frequency is the group of semantic complementary expressions. The semantic method of making meaning is based on the identification features of a general contour of a word-stimulus at the level of meaning. This method requires understanding and awareness of the meaning of derived compliments and the respondent's ability to deploy the semantic content of statements. Associative meaning-making, taking into account the principle of semantic adjacency, requires native speakers to form logically structured semantic connections between associate words, and therefore the associative pair is formatted based on the analysis of deep tiers of meaning and understanding the logical-semantic context within the associative-semantic field. Semantically identical words which denote associations are determined by common processes of semantic derivation, which are united in this group lexical-semantic variants of words according to the principle of analogy, the intersection of explicit and implicit meanings. The actualization of the semantic space of the respondent's philological consciousness in the paradigm of logical subordination causes partial replacement of elementary components of the meaning of the derived word with adjacent sema, which were not explicitly expressed in the stimulus word, but can be semantically derived from it by associative logical meanings.

Semantically related (by a way of belonging) statements are used equally by both English and Ukrainians (the difference in the results is insignificant, $\mathrm{r}=1.431, \rho<0.028)$. Such compliments are used by Englishmen: pretty - fine; brave; handsome; little; kind; intelligent; interesting; у українців: among Ukrainians they are: 
гарна - фантастична; таємнича - мрійлива; тактовна - чудова. Also, there is no significant difference in a case of use by two groups of respondents semantically related compliments (they are formed by the method of identity, $r=1.344, \rho<0.030$ ). Englishmen use such examples of compliments: nice - beautiful; smart - clever; splendid - beautiful - attractive - nice; among Ukrainians they are: турботлива - добра; щүиосердечна - добра; струнка - граціозна; бездоганна - приваблива - гармонійна; зроблена - мила - ніжна; блаженна - природна; дивна - чудова; мініатюрна - струнка. Statistically significant at the level $\rho<0.05$ of significance of differences in results is the difference in the frequency of use of semantically similar compliments, which are most often used by Ukrainians: мила - чарівна; непереборна - неповторна; енергійна - запальна; безкорислива безпосередня; життерадісна - усмішлива; чесна - щзиосердна. Ukrainians also use more semantically related compliments, formed by the way of logical adjectivation $(\mathrm{r}=3.425, \rho<0.01)$. Examples of such compliments are: розумна - незабутня; сліпуча - жагуча; фантастична - божественна; заворожлива - ангельська; пекельно божественна - яскрава; загадкова - інтригуючи; природна скромна; дружелюбна - розуміюча; іскрометна - хвилююча; усмішлива - запальна; симпатична - казкова; сама-сама - чудесна; in English: wonderful - lovely; wise; splendid - beautiful; perfect special; brilliant - good-looking; blooming - charming.

Formal complementary statements are mostly used by Englishmen, although the difference in results between Ukrainians and Englishmen is significant at the level of $\rho<0.05$ only for objective phonetic statements $(\mathrm{r}=2.988, \rho<0.05)$. To this group of compliments we include: good - well; nice - good; fine; well; among Ukrainians there are: добра - ніжна; чарівна - чаруюча; щүиросердечна - щиира; струнка - витончена; приваблива - ваблива; чудесна - чудова. Examples of stereotypical and lexical compliments in the English language are: sweet - charming; great - nice; among Ukrainians: бажана - сексуальна; жагуча - яскрава; божественна - пекельно божественна; пригарна - звабна; витончена - грачіозна; весела енергійна; щзира - щчиросердна (Table 3).

Also quite interesting there are results of syntagmatic complementary statements. Thus, word combinations are much more 
often used by Englishmen $(\mathrm{r}=3.471, \rho<0.01)$, while sentences are used by Ukrainians $(r=3.492, \rho<0.01)$.

Table 3. The results of the frequency of use the methods of explication of compliments by representatives of Ukrainian and English ethnic groups

\begin{tabular}{|c|c|c|c|c|}
\hline \multirow{3}{*}{$\begin{array}{l}\text { The ways of } \\
\text { explication of } \\
\text { compliments }\end{array}$} & \multicolumn{4}{|c|}{$\begin{array}{c}\text { THE RESULTS OF REPRESENTATIVES OF DIFFERENT } \\
\text { ETHNIC GROUPS AND PARAMETERS OF STATISTICAL } \\
\text { RELIABILITY OF DIFFERENCES IN WAYS OF } \\
\text { EXPLICATION THE COMPLIMENTS }\end{array}$} \\
\hline & \multicolumn{2}{|c|}{$\begin{array}{l}\text { Absolute frequency of ways of } \\
\text { explication of compliments }\end{array}$} & \multicolumn{2}{|c|}{$\begin{array}{l}\text { The results of one-factor } \\
\text { analysis of variance }\end{array}$} \\
\hline & Englishmen & Ukrainians & $\begin{array}{l}\text { Fisher's } \\
\text { F-criteria }\end{array}$ & $\begin{array}{l}\text { The level of } \\
\text { significance of } \\
\text { differences in } \\
\text { results, } \rho\end{array}$ \\
\hline \multicolumn{5}{|c|}{ Formal complements } \\
\hline Objective phonetic & 23.5 & 8.3 & 2.988 & $0.05 *$ \\
\hline $\begin{array}{l}\text { Stereotypical and } \\
\text { lexical }\end{array}$ & 16.7 & 10.6 & 1.563 & 0.031 \\
\hline \multicolumn{5}{|c|}{ Semantic complements } \\
\hline Semantically similar & 0.5 & 14.8 & 2.831 & $0.05 *$ \\
\hline $\begin{array}{l}\text { Semantically related } \\
\text { (by the way of } \\
\text { belonging) }\end{array}$ & 21.4 & 18.7 & 1.431 & 0.028 \\
\hline $\begin{array}{l}\text { Semantically related } \\
\text { (by the way of } \\
\text { identity) }\end{array}$ & 27.9 & 30.6 & 1.344 & 0.030 \\
\hline $\begin{array}{l}\text { Semantically related } \\
\text { (by the way of logical } \\
\text { adjectivation) }\end{array}$ & 20.5 & 42.3 & 3.425 & $0.01 *$ \\
\hline \multicolumn{5}{|c|}{ Subjective (ideosyncrasic) complements } \\
\hline Emotionally evaluative & 46.8 & 18.9 & 3.318 & $0.01 *$ \\
\hline Creative & 15.6 & 49.4 & 3.458 & $0.01 *$ \\
\hline \multicolumn{5}{|c|}{ Syntagmatic complements } \\
\hline $\begin{array}{l}\text { Syntactical } \\
\text { constructions (phrases) }\end{array}$ & 52.6 & 18.3 & 3.471 & $0.01 *$ \\
\hline $\begin{array}{l}\text { Syntactical } \\
\text { constructions } \\
\text { (sentences) }\end{array}$ & 19.7 & 57.8 & 3.492 & $0.01 *$ \\
\hline
\end{tabular}

Symbols:

* - the results are significant at the levels of significance of differences: 0.05 and 0.01. 
In order to highlight the psycholinguistic features of the explication of compliments in English and Ukrainian, the procedure of correlation analysis was used. The results are shown by Fig. 1, 2 .

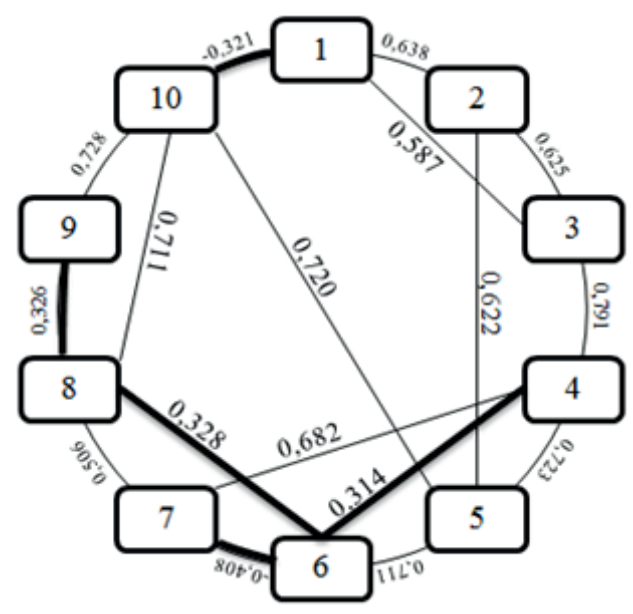

Fig. 1. Correlation of the ways of explication the compliments by respondents of Ukrainian ethnic group (in points, according to the results of correlation analysis)

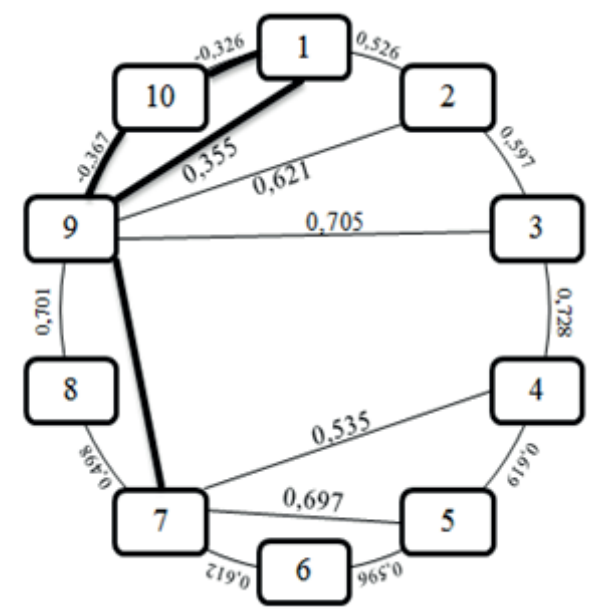

Fig. 2. Correlation of the ways of explication the compliments by respondents of English ethnic group (in points, according to the results of correlation analysis)

\section{Symbols:}

The ways of explication of compliments:

1 - objective phonetic;

2 - stereotypical and lexical;

3 - semantically similar;

4 - semantically related (by the way of belonging);

5 - semantically related (by the way of identity);

6 - semantically related (by the way of logical adjectivation);

7 - emotionally evaluative;

8 - creative;

9 - syntactical constructions (phrases);

10 - syntactical constructions (sentences);

- correlation is significant on the level 0.01 of the significance of differences of the results;

- correlation is significant on the level 0.05 of the significance of differences of the results.

According to our results, among the respondents of the Ukrainian ethnic group we diagnosed the largest number of positive correlations between: 
- the way of the explication of compliments in a form of a sentence and: syntactic constructions (phrases) $(\mathrm{r}=0.728, \rho<0.01)$; semantically related compliments formed by the way of identity $(\mathrm{r}=0.720, \rho<0.01)$; creative compliments $(\mathrm{r}=0.711, \rho<0.01)$;

- semantically related compliments formed by the way of logical adjectivation and: semantically related compliments formed by the way of identity $(\mathrm{r}=0.711, \rho<0.01)$; semantically related compliments formed by the way of belonging $(r=0.314, \rho<0.05)$; creative compliments $(\mathrm{r}=0.328, \rho<0.05)$;

- semantically related compliments formed by the way of identity and: semantically related compliments formed by the way of belonging $(\mathrm{r}=0.723, \rho<0.01)$; compliments, expressed in a form of a sentence $(r=0.720, \rho<0.01)$; semantically related compliments formed by the way of logical adjectivation $(\mathrm{r}=0.711, \rho<0.01)$; stereotypical and lexical compliments $(\mathrm{r}=0.622, \rho<0.01)$.

Significant negative correlations were diagnosed in accordance with respondents of the Ukrainian ethnic group between:

- semantically related compliments formed by the way of logical adjectivation and emotional-evaluative compliments $(r=-0.408, \rho<0.05)$;

- by the way of explication of compliments in a form of a sentence and objective phonetic constructions $(r=-0.321, \rho<0.05)$.

In turn, the respondents of the English ethnic group had the highest number of positive correlations between:

- the way of the explication of compliments in a form of phrases and: semantically similar compliments $(\mathrm{r}=0.705, \rho<0.01)$; creative compliments $(\mathrm{r}=0.701, \rho<0.01)$; stereotypical and lexical compliments $(\mathrm{r}=0.621, \rho<0.01)$; emotional and evaluative compliments $(\mathrm{r}=0.397$, $\rho<0.05)$; objective-phonetic constructions ( $\mathrm{r}=0.355, \rho<0.05)$;

- emotional and evaluative compliments and: semantically related compliments formed by the way of identity $(r=0.697, \rho<0.01)$; semantically related compliments formed by the way of logical adjectivation $(\mathrm{r}=0.612, \quad \rho<0.01)$; semantically related compliments formed by the way of belonging $(\mathrm{r}=0.535, \rho<0.01)$; creative compliments $(r=0.498, \rho<0.01)$; compliments formed by the way of explication of them in the form of a phrase $(r=0.397, \rho<0.05)$.

Significant negative correlations were diagnosed in a case of respondents of the English ethnic group between:

- the way of the explication of compliments in the form of phrases and sentences $(r=-0.367, \rho<0.05)$; 
- the way of the explication of compliments in the form of a sentence and objective-phonetic constructions $(r=-0.326, \rho<0.05)$.

\section{Conclusions}

In both Ukrainian and English, a compliment is the independent, free expression, it is not the result of a request from the side of the addressee. Saying compliments, English people usually use either formulas of speech etiquette due to social norms, or expressions in the narrow sense of the word, such as emotionally evaluative expressions (therefore emotionally evaluative compliments have a fairly high level of the expression). Englishmen sincerely express their emotions by the informal compliments, which, according to our research, do not necessarily take place among people who love each other, among relatives, but this act is done solely in the interests of a speaker. In most cases, the proclamation of a complementary act is determined by a specific pragmatic situation. Therefore, only on the basis of each case from the context, which implies taking into account the goals and motives of the speaker, the nature of his/her relationships with the addressee, you can more clearly define the type of speech complementary act.

The compliments of the Ukrainian ethnic group show a certain psychological state of the addressee, they are not as strictly connected with social norms and rules as English ones. Considering the compliments having been said by the representatives of the Ukrainian ethnic group, it should be emphasized the perlocutionary effect of these expressions, because emotional and evaluative statements of representatives of the Ukrainian ethnic group play a special kind of illocutionary acts, with the aim to cause the perlocutionary effect from the side of the addressee and evaluative response.

Compliments having been said by the members of the Ukrainian ethnic group are usually constructed using logical suggestions, so when a subject says a compliment it primarily implies that he/she has certain thoughts, feelings, intentions, and his/her speech act has the aim to facilitate a certain behavior of the addressee.

Representatives of the Ukrainian ethnic group form the compliments in different ways, but the choice of one variant from several alternative structures is quite pragmatic. Complementary 
statements not only describe the denotative situation, but also convey the nature of the relationships between partners of the communication and show the context of the communication process itself. At the same time, the context displays the interest to Ukrainians if there is a real possibility of the speaker's influence on the semantics of statements. Even synonymous statements can be perceived quite differently: they can emphasize different aspects of situations, as well as to convey the nature of the relationships between the speaker and the addressee or to characterize the different attitudes to the content having been said, because it emphasizes the pragmatic aspect of speech.

Thus, we'll formulate the psycholinguistic features of the explication of compliments in Ukrainian and English languages. Such features are:

- respondents of both Ukrainian and English ethnic groups are characterized by dominated subjective (ideosyncrasic) way of forming complementary expressions. English respondents are also dominated by emotional and evaluative way, while Ukrainians - by creative way in modeling the compliments. English people are more emotional in choosing phrases, word combinations and speech patterns that are complementary expressions, their speech is characterized by expressiveness and imagery. In turn, Ukrainians are more able to form creative expressions in their content, they form associative schemes, which, on the one hand, seem illogical, but, on the other hand, contain a creative context that enriches speech in a great degree;

- semantic compliments are used equally by both English and Ukrainians, but Ukrainians use more semantically similar and semantically related compliments, as well as compliments based on the principle of logical adjectivation;

- formal complementary expressions are used more by the Englishmen, in addition, they are closely related to social norms, values and ideals;

- phrases are much more often used by Englishmen, while sentences are used by Ukrainians on the contrary. This indicates deeper, subjective meaning, personality oriented nature of complementary statements among the respondents of the Ukrainian ethnic group.

Our research does not touch upon all aspects of the problem field of the development of complementary statements in the paradigm of logical-semantic and emotional-evaluative organization of speech of 
Ukrainian and English ethnic groups, but opens prospects for further study, for example, if we tell about the study of cognitive and expressive mechanisms of forming the philological consciousness of Englishmen and Ukrainians.

\section{References}

Aleksandrov, A.A., Memetova, K.S., \& Stankevich, L.N. et. al. (2020). Referent's Lexical Frequency Predicts Mismatch Negativity Responses to New Words Following Semantic Training. Journal of Psycholinguistic Research, 49, 187-198. https://doi.org/10.1007/s10936-019-09678-3

Alexandrov, A.A., Boricheva, D.O., Pulvermüller, F., \& Shtyrov, Y. (2011). Strength of word-specific neural memory traces assessed electrophysiologically. PLoS ONE, 2-29. https://doi.org/10.1371/journal.pone.0022999

Andrews, V. (1990). Web of Dreams. Glasgow: Collins.

Arbuthnott, K., \& Frank, J. (2000). Executive control in set switching: Residual switch cost and task-set inhibition. Canadian Journal of Experimental Psychology, 54, 33-41. https://doi.org/10.1037/h0087328

Batel, E. (2020). Context Effect on L2 Word Recognition: Visual Versus Auditory Modalities. Journal of Psycholinguist Research, 49, 223-245. https://doi. org/10.1007/s10936-019-09683-6

Bates, D., Maechler, M., Bolker, B., \& Walker, S. (2014). lme4: Linear mixed-effects models using Eigen and S4. Journal of Package Version, 1(7), 1-23. https://doi. org/10.18637/jss.v067.i01

Beauvillain, C. (1994). Morphological structure in visual word recognition: Evidence from prefixed and suffixed words. Language and Cognitive Processes, 9(3), 317 339. https://doi.org/10.1080/01690969408402122

Blagovechtchenski, E., Gnedykh, D., Kurmakaeva, D. et. al. (2019). Transcranial direct current stimulation (tDCS) of Wernicke's and Broca's areas in studies of language learning and word acquisition. Journal of Visualized Experiments, 3759. https://doi.org/10.3791/59159

Booth, J.R., MacWhinney, B., \& Harasaki, Y. (2000). Developmental differences in visual and auditory processing of complex sentences. Child Development, 71(4), 981-1003. https://doi.org/10.1111/1467-8624.00203

Brédart, S. (1991). Word interruption in self-repairing. Journal of Psycholinguistic Research, 20, 123-137.

Caramazza, A., Laudanna, A., \& Romani, C. (1988). Lexical access and inflectional morphology. Cognition, 28(3), 297-332. https://doi.org/10.1016/00100277(88)90017-0

Carter, D. (2015). Fatherless sons. Moscow: Foreign Language Publishing House.

Chen, R. (1993). Responding to Compliments. A Contrastive Study of Politeness Strategies between American English and Chinese Speakers. Journal of Pragmatics, 20(1), 49-73. https://doi.org/10.1016/0378-2166(93)90106-Y

Cilibrasi, L., Stojanovik, V., Riddell, P., \& Saddy, D. (2019). Sensitivity to Inflectional Morphemes in the Absence of Meaning: Evidence from a Novel Task. Journal of Psycholinguist Research, 48, 747-767. https://doi.org/10.1007/s10936-019-09629-y

Cronin, A. (1957). The Citadel. Moscow: Foreign Languages Publishing House. 
Crookes, G. (1989). Planning and interlanguage variation. Studies in Second Language Acquisition, 11, 367-383. https://doi.org/10.1017/S0272263100008391

Bot, de K. (1992). A bilingual production model: Levelt's «speaking» model adapted. Applied Linguistics, 13, 1-24. https://doi.org/10.1093/applin/13.1.1

Derwing, T.M., Munro, M.M., Thomson, R.I., \& Rossiter, M.J. (2009). The relationship between L1 fluency and L2 fluency development. Studies in Second Language Acquisition, 31, 533-557. https://doi.org/10.1017/S0272263109990015

Dijkgraaf, A., Hartsuiker, R.J., \& Duyck, W. (2017). Predicting upcoming information in native-language and non-native-language auditory word recognition. Bilingualism: Language and Cognition, 20(5), 917-930. https://doi.org/10.1017/ S1366728916000547

Ellis, J. (1991). Maison Jennie. London: Crafton.

Ellis, R. (1987). Interlanguage variability in narrative discourse: Style shifting in the use of the past tense. Studies in Second Language Acquisition, 9, 12-20. https:// doi.org/10.1017/S0272263100006483

Ferreira, F., Henderson, J.M., Anes, M.D., Weeks, P.A., \& McFarlane, D.K. (1996). Effects of lexical frequency and syntactic complexity in spoken-language comprehension: Evidence from the auditory moving-window technique. Journal of Experimental Psychology. Learning, Memory, and Cognition, 22(2), 324. https://doi.org/10.1037/0278-7393.22.2.324

Fodor, J.A. (1983). The Modularity of mind. Cambridge, MA: MIT Press. https://doi. org/10.7551/mitpress/4737.001.0001

Galsworthy, J. (1975). The Forsyte Saga. Book I. The Man of Property. Moscow: Progress Publishers.

Gilabert, R. (2007). Effects of manipulating task complexity on self-repairs during L2 oral production. International Review of Applied Linguistics, 45, 215-240. https:// doi.org/10.1515/iral.2007.010

Goffman, E. (1981). Forms of Talk. Philadelphia: University of Pennsylvania Press.

Green, D.W. (1998). Mental control of the bilingual lexico-semantic system. Bilingualism: Language and Cognition, 1(2), 67-81. https://doi.org/10.1017/ S1366728998000133

Hatzidaki, A., Baus, C., \& Costa, A. (2015). The way you say it, the way I feel it: Emotional word processing in accented speech. Frontiers in Psychology, 6, 351. https://doi.org/10.3389/fpsyg.2015.00351

Herbert, R.K. (1989). The Ethnography of Compliments and Compliment Responses: A Contrastive Sketch. Contrastive Pragmatics, 3-35. https://doi.org/10.1075/ pbns.3.05her

Herbert, R.K. (1990). Sex-based Differences in Compliment Behavior. Language in Society, 19, 201-224. https://doi.org/10.1017/S0047404500014378

Kormos, J. (1999). The effect of speaker variables on the self-correction behavior of L2 learners. System, 27, 207-221. https://doi.org/10.1016/S0346-251X(99)00017-2

Kotlyarevskyi, I. (1982). Eneida. Poetychni tvory. Dramatychni tvory. Lysty [The Aeneid. Poetry. Dramatic stories. Letters]. Kyiv [in Ukrainian].

Lagrou, E., Hartsuiker, R.J., \& Duyck, W. (2013). The influence of sentence context and accented speech on lexical access in second-language auditory word recognition. Bilingualism: Language and Cognition, 16(3), 508-517. https://doi. org/10.1017/S1366728912000508

Levelt, W.J.M. (1983). Monitoring and self-repair in speech. Cognition, 33, 41-103. https://doi.org/10.1016/0010-0277(83)90026-4 
Lu, A., Wang, L., Guo, Y., Zeng, J. et. al. (2019). The Roles of Relative Linguistic Proficiency and Modality Switching in Language Switch Cost: Evidence from Chinese Visual Unimodal and Bimodal Bilinguals. Journal of Psycholinguist Research, 48, 1-18. https://doi.org/10.1007/s10936-017-9519-6

Maurier, du. D. (1978). Hungry Hill. London: Victor Gollangz LTD.

McClelland, J.L., \& Elman, J.L. (1986). The TRACE model of speech perception. Cognitive Psychology, 18(1), 1-86. https://doi.org/10.1016/0010-0285(86)90015-0

Mitchel, M. (1973). Gone with the Wind. New-York: Avon Books.

Mykhalchuk, N., \& Bihunova, S. (2019). The verbalization of the concept of «fear» in English and Ukrainian phraseological units. Cognitive Studies - Etudes cognitives, 19, 11. https://doi.org/10.11649/cs.2043

O’Brien, I., Segalowitz, N., Freed, B., \& Collentine, J. (2007). Phonological memory predicts second language oral fluency gains in adults. Studies in Second Language Acquisition, 29, 557-581. https://doi.org/10.1017/S027226310707043X

O’Donnell, J., MacGregor, L., Dabrowski, J., Oestreicher, J., \& Romero, J. (1994). Construct validity of neuropsychological tests of conceptual and attentional abilities. Journal of Clinical Psychology, 50, 596-600. https://doi. org/10.1002/1097-4679(199407)50:4<596::AID-JCLP2270500416>3.0.CO;2-S

Pilcher, R. (1992). Collection, II. London: Coronet Books.

Pinker, S. (1991). Rules of language. Science, 253(5019), 530. https://doi.org/10.1126/ science. 1857983

Salinger, J.D. (1982). Selected Works. Moscow: Progress Publishers.

Schwartz, A.I., \& Kroll, J.F. (2006). Bilingual lexical activation in sentence context. Journal of Memory and Language, 55(2), 197-212. https://doi.org/10.1016/j. jml.2006.03.004

Sgall, P. (1986). The Meaning of the Sentence in its Semantic and Pragmatic Aspects. Prague: Academia.

Shaffer, P. (1984). Five Finger Exercise. Modern English Drama (pp. 33-157). Moscow: Raduga.

Taft, M. (2013). Reading and the mental lexicon. Hove: Psychology Press. https://doi. org/10.4324/9780203765357

Bradford, B.T. (1990). Hold the Dream. London: Grafton Books.

Tereshko, L. (2019). Svitlo liubovi: virshi [The light of Love: poems]. Rivne [in Ukrainian].

Ullman, M.T. (2001). A neurocognitive perspective on language: The declarative/ procedural model. Nature Reviews Neuroscience, 2(10), 717-726. https://doi. org/10.1038/35094573

Valis, M., Slaninova, G., Prazak, P. et. al. (2019) Impact of Learning a Foreign Language on the Enhancement of Cognitive Functions Among Healthy Older Population. Journal of Psycholinguist Research, 48, 1311-1318. https://doi. org/10.1007/s10936-019-09659-6

Ware, C., Damnee, S., Djabelkhir, L. et al. (2017). Maintaining cognitive functioning in healthy seniors with a technology-based foreign language program: A pilot feasibility study. Frontiers in Aging Neuroscience, 9, 42. https://doi.org/10.3389/ fnagi.2017.00042

Wilde, O. (1961). Plays. Moscow: Foreign Languages Publishing House.

Zuniga, M., \& Simard, D. (2019). Factors Influencing L2 Self-repair Behavior: The Role of L2 Proficiency, Attentional Control and L1 Self-repair Behavior. Journal of Psycholinguist Research, 48, 43-59. https://doi.org/10.1007/s10936-018-9587-2 


\section{АНОТАЦІЯ}

Мета дослідження: схарактеризувати функціональний аспект компліментів в англійській та українській мовах; описати відмінності між похвалою, лестощами та компліментами; проаналізувати систему актуальних способів моделювання асоціативного контенту смислів компліментарних висловлювань у семантичному полі філологічної свідомості респондентів різних етнічних груп. Методи дослідження: теоретичні - категоріальний та структурнофункціональний аналіз авторських текстів, методи систематизації, моделювання, узагальнення; емпіричні методи - аналіз літературних творів, вільний асоціативний експеримент.

Результати. Визначено, що у респондентів української етнічної групи найбільшу кількість позитивних кореляційних зв'язків діагностовано між: способом експлікації компліментів у фрормі речення та: синтаксичними конструкціями (словосполученнями); семантично суміжними компліментами, утвореними за способом тотожності; креативними компліментами; семантично суміжними компліментами, утвореними за способом логічної ад'єктивації та: семантично суміжними компліментами, утвореними за способом тотожності; семантично суміжними компліментами, утвореними за способом приналежності та ін. У респондентів англійської етнічної групи найбільшу кількість позитивних кореляційних зв'язків діагностовано між: способом експлікації компліментів у формі словосполучення та: семантично подібними компліментами; креативними компліментами; емоційно-оцінними компліментами та: семантично суміжними компліментами, утвореними за способом тотожності; семантично суміжними компліментами, утвореними за способом логічної ад'єктивації та ін.

Висновки. Сорормульовано психолінгвістичні особливості експлікації компліментів в українській та англійській мові. Такими особливостями $\epsilon:$ у респондентів як української, так і англійської етнічної групи домінувальним $\epsilon$ суб'єктивний (ідеосинкразичний) спосіб утворення компліментарних висловлювань, при цьому у респондентів-англійців переважає емоційно-оцінний спосіб, тоді як у українців - креативний тощо. Англійці є більш емоційними у виборі словосполучень, фраз, які відносяться до компліментарних висловлювань, їх мовлення характеризується експресивністю та образністю. Українці здатні до більшою мірою утворення креативних висловлювань за своїм змістом, вони утворюють асочіативні схеми, які, з одного боку, здаються нелогічними, проте, з другого боку, вмішують креативний контекст, який збагачує мовлення та ін.

Ключові слова: смислове поле, психолінгвістичні особливості експлікації компліментів, похвали, лестощів, креативні компліменти, логічна ад'єктивація, емоційно-оцінні компліменти, семантично суміжні компліменти.

Ивашкевич Эрнест, Перишко Ирина, Кочур Сабина \& Чернишова Светлана. Психолингвистический контент комплиментарных высказываний в английском и украинском языках 


\section{АННОТАЦИЯ}

Цель исследования: дать характеристику функциональному аспекту комплиментов в английском и украинском языках; описать различия между похвалой, лестью и комплиментами; проанализировать систему актуальных способов моделирования ассоциативного контента смыслов комплиментарных высказываний в семантическом поле филологического сознания респондентов различных этнических групп.

Методы исследования: теоретические - категориальный и структурнофункциональный анализ авторских текстов, методы систематизации, моделирования, обобщения; эмпирические методы - анализ литературных произведений, свободный ассоциативный эксперимент.

Результаты. Определено, что у респондентов украинской этнической группы наибольшее количество положительных корреляционных связей диагностировано межуу: способом экспликации комплиментов в форме предложения и: синтаксическими конструкциями (словосочетаниями) и семантически тождественными комплиментами, образованными способом тождественности; креативными комплиментами; семантически тождественными комплиментами, образованными способом логической адъективации, и: семантически тождественными комплиментами, образованными способом тождественности; семантически тождественными комплиментами, образованными способом принадлежности и др. У респондентов английской этнической группы диагностировано наибольшее количество положительных корреляционных связей между: способом экспликации комплиментов в форме словосочетания и: семантически похожими комплиментами; креативными комплиментами; эмоционально-оценочными комплиментами и: семантически тождественными комплиментами, образованными способом тождественности; семантически тождественными комплиментами, образованными способом логической адъективации и др.

Выводы. Сформулированы психолингвистические особенности экспликации комплиментов в украинском и английском языках. Такими особенностями являются: у респондентов как украинской, так и английской этнической групп доминирующим является субъективный (идеосинкразический) способ образования комплиментарных высказываний, при этом у респондентовангличан преобладает эмоционально-оценочный способ, тогда как в украинской этнической группе - креативный способ. Англичане - более эмочиональные касательно выбора словосочетаний, фраз, относящихся к комплиментарным высказываниям, их речь характеризуется экспрессивностью и образностью. Украинцы способны в больщей степени, по сравнению с англичанами, $к$ образованию креативных высказываний, они моделируют ассоциативные схемы, которые, с одной стороны, кажутся нелогичными, однако, с другой стороны, содержат креативный контекст, обогащающий речь и т. п.

Ключевые слова: смысловое поле, психолингвистические особенности экспликации комплиментов, похвалы, лести, креативные комплименты, логическая адьективачия, эмоционально-оценочные комплименты, семантически тождественные комплименты. 